\title{
Mechanical behavior of primary cilia
}

\author{
CR Jacobs ${ }^{* *}$, ME Downs ${ }^{1}$, AM Nguyen ${ }^{1}$, FA Herzog ${ }^{2}$, DA Hoey ${ }^{3}$ \\ From First International Cilia in Development and Disease Scientific Conference (2012) \\ London, UK. 16-18 May 2012
}

We have developed a novel combined experimental/ modeling approach to determine the mechanical properties of primary cilia. Specifically, we developed a large rotation formulation of cilia bending with fluid flow that accounts for rotation at the base of the cilium, the initial shape of the cilium and fluid drag at high deflection angles. We also have obtained three dimensional configurations of primary cilia in their deformed configuration at $3 \mathrm{~Hz}$ acquired with high-speed confocal microscopy. We found a wide variety of previously unreported bending shapes and behaviors. Cilia appear to deflect in smooth bending shapes, rigid-body rotation, and in a hinged or kinked pattern. This suggests that both the axoneme and basal body anchorage are important to understanding deflection patterns. We also analyzed post-flow relaxation patterns. These results indicate that with removal of force, cilia slowly return to their initial configuration. However, they also can return to a different configuration with "overcorrection" observed that suggests adaptation of mechanical properties. Results from our combined experimental and theoretical approach suggest that the average flexural rigidity of primary cilia might be higher than previously reported. In addition our findings indicate the mechanics of primary cilia are potentially non-linear, richly varied, and mechanisms may exist to alter their mechanical behavior.

\section{Author details}

${ }^{1}$ Columbia University, NY, USA. ${ }^{2}$ Ecole Polytechnique Federale de Lausanne, Switzerland. ${ }^{3}$ Trinity Collage Dublin, Ireland.

Published: 16 November 2012

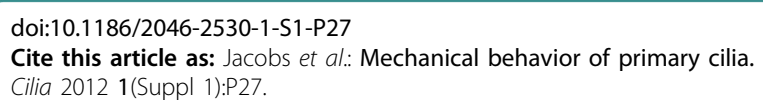

${ }^{1}$ Columbia University, NY, USA

Full list of author information is available at the end of the article
Submit your next manuscript to BioMed Central and take full advantage of:

- Convenient online submission

- Thorough peer review

- No space constraints or color figure charges

- Immediate publication on acceptance

- Inclusion in PubMed, CAS, Scopus and Google Scholar

- Research which is freely available for redistribution
C Biomed Central 